\title{
TIDAL REGIMS OF ARAFURA AND TIMOR SEA
}

\author{
Widodo S. Pranowo ${ }^{1}$ and Sugiarta Wirasantosa ${ }^{2}$ \\ ${ }^{1}$ Research \& Development Centre for Marine \& Coastal Resources \\ Ministry of Marine Affairs \& Fisheries, Republic of Indonesia \\ ${ }^{2}$ Agency for Marine \& Fisheries Research \& Development \\ Ministry of Marine Affairs \& Fisheries, Republic of Indonesia \\ E-mail: widodo.pranowo@kkp.go.id
}

Received: June 2011

Accepted: July 2011

\begin{abstract}
Tidal range in the Arafura and Teimor Sea region is estimated from the actual field records collected by five tidal stations during March 2011. These stations include Rote and Saumlaki tidal stations of Badan Koordinasi Survei dan Pemetaan Nasional (Bakosurtanal) Indonesia, and Broome, Darwin and Groote Eylandt tidal stations of Australia Bureau of Meteorology (BoM). In addition to data from these stations, datasets of sea surface height obtained from Topex/Poseidon altimetry at seven (7) virtual stations were used. Generally, the results of this study are in agreement with that of Wyrtki (1961). However, by utilizing spectral analysis and form factor, this study shows difference in terms of tidal types from that of Wyrtki's, particularly at Karumba and Groote Eylandt stations.
\end{abstract}

Keywords: tidal regim, Arafura Sea, Timor Sea, surface current

\section{INTRODUCTION}

Tidal range is one of the main factors in generating surface current and watermass flow due to sea level gradient or the difference of sea level. Daily tidal movement affects socio-economic life of coastal people in terms of socio-economic activities, resource utilization, and resource management. Therefore, tidal range character in an area is an important parameter to be considered in coastal zone planning, coastal economic activities such as aquaculture and other economic and conservation related trans-boundary activities such those among Indonesia, Timor Leste, and Australia (Sihotang, 2010).

Arafura and Timor Sea are categorized as semi-enclosed sea according to UNCLOS (U.N Convention on the Law of the Sea), where their bathymetry covers continental shelf of Australia and Timor through with various depths (IHO map sheet 3). Average depths of the Arafura Sea range from $30 \mathrm{~m}$ to $90 \mathrm{~m}$ and that of the Timor Sea range from $50-120 \mathrm{~m}$ (ATSEA, 2010). The depth deepens to $3000 \mathrm{~m}$ in the Timor through that runs parallel to the Island of Timor (GEBCO, 2008).
Bathymetry of the Arafura-Timor Sea region affects the oceanographic character of water mass flow between the Indian and Pacific Ocean, for instance, the connectivity of deep watermass between Pacific Ocean and Indian Ocean is blocked by the shallow Torres Strait and therefore, the deep Pacific watermass flows through deeper channels such as Makassar Strait and other smaller straits in the area.

Fresh water input to the Arafura Sea mainly comes from southwest flowing rivers in Papua and some rivers flowing to the Gulf of Carpentaria and northern Australia with continuing submerged tributaries in the shelf area. Smaller amount of fresh water inputs may come from Aru, Yamdena and Kei Islands. In the Timor Sea, however, fresh water input mainly comes from northward flowing rivers in the northern Australia and seasonally may come from southward flowing tributaries in Timor Island.

This article presents an assessment of tidal characteristic in Arafura Timor Seas area based on real data collected by tidal stations around the region with an intention of contributing a 
knowledge in one of the physical characters of the area to be considered in the planning and activities development of Arafura Timor Seas Environmental Action (ATSEA) program. The data and information produced from this study also serve as an update to the prevailing basic information (Wyrtki, 1961) of the given area.

\section{METHODS}

Datasets which are used in this article are provided at Rote and Saumlaki tidal stations of Badan Koordinasi Survei dan Pemetaan Nasional (Bakosurtanal) Indonesia, and Broome, Darwin and Groote Eylandt tidal stations of Australia Bureau of Meteorology (BoM) within the periode of 01-30 March 2011. However, considering the limited number of accessible tidal stations in the area and in order to have a better representation of tidal characteristics in the Arafura and Timor Seas region we use additional datasets of sea surface height obtained from Topex/Poseidon altimetry at seven virtual stations, that include Ombai, Timor, Tanimbar Northeast, Papua-1, Papua-2 and Karumba. Fig. 1 shows the distribution of tidal stations in the Arafura and Timor Seas region.
Tidal datasets from five stations in 30 days duration with 1 minute interval were used to determine the tidal characteristics in the studied area. Examples of detailed characteristics of tidal curves from Rote, Broome, Saumlaki, Darwin, and Groote Eylandt are shown in Figure 3 to 7. These curves serve as examples of tidal characteristics in the first five days of 30 days data from the mentioned stations. Additional tidal constituents were derived from TOPEX/Poseidon altimetry data and tide gauges by employing the Oregon State University Tidal Inversion Software (Egbert and Erofeeva, 2002). Assimilation of the two datasets was done by applying the method similar to that was used by Setiawan (2007). The non-harmonic components were removed from the time series data (Walters and Heston, 1982), and the types of tidal could be revealed after the form factor has been computed (Pugh, 1987). Confirmation of the form factor resulted from the calculation was done through a powerful and accurate means of spectral analysis employing Fast Fourier Transform (FFT) (Emery and Thomson, 2004).

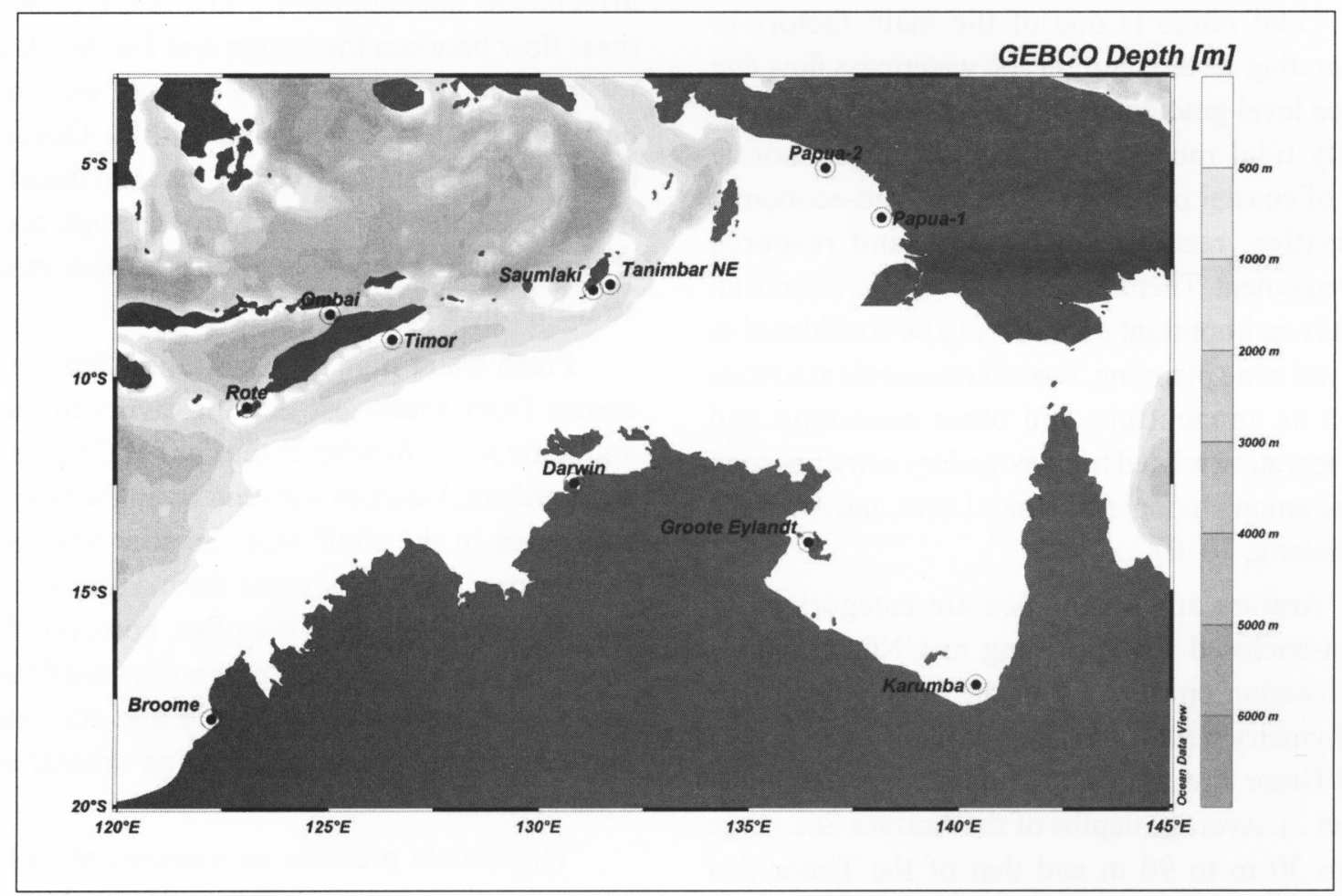

Figure 1. Distribution of tidal stations in the Arafura-Timor seas region that were used in this study. Existing stations are Bakosurtanal's Saumlaki and Rote and BoM Australia's Broome, Darwin, and Groote Eylandt. Additional virtual stations are Ombai, Timor, Tanimbar Northeast, Papua-1, Papua-2, and Karumba. 


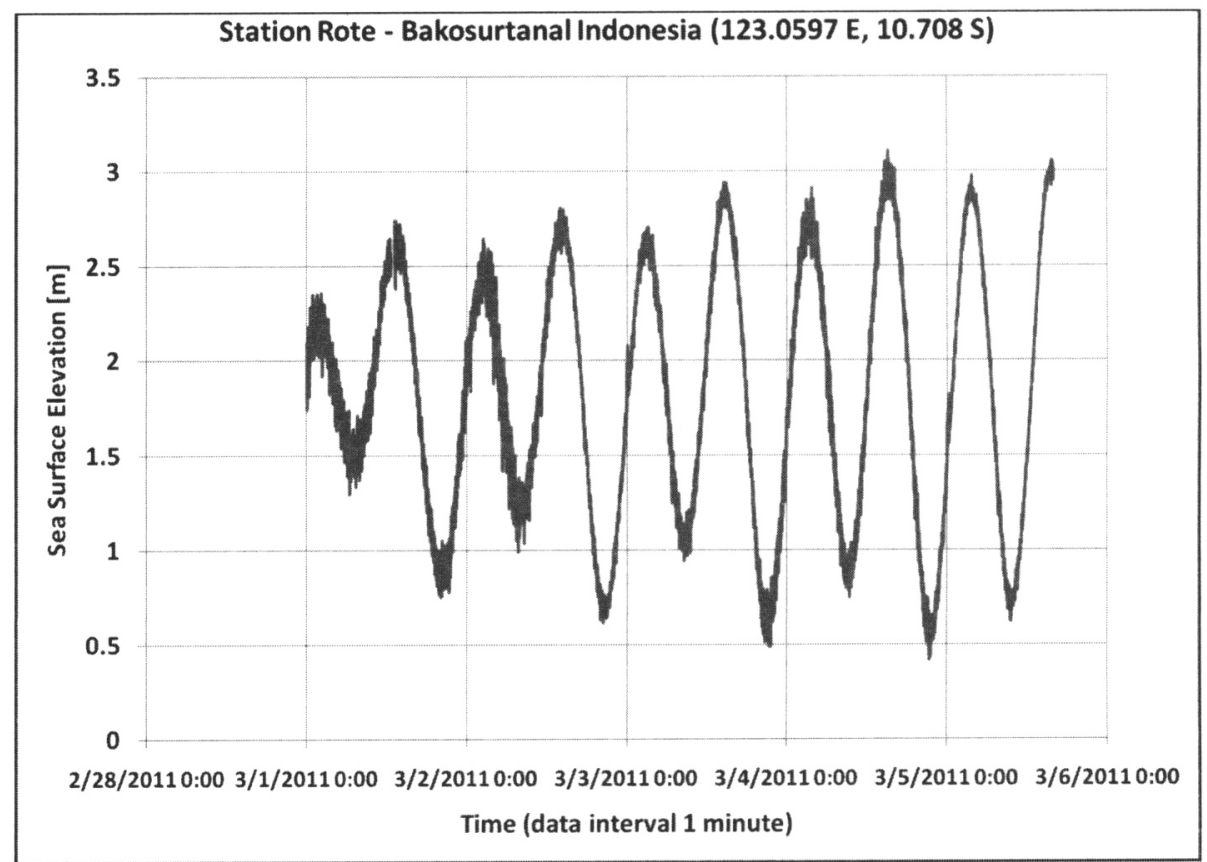

Figure 3. Example of sea surface detail at Rote Station as observed during 1-5 March 2011. The detailed curves are part of the 30 days observation used in the estimation of tidal characteristics.

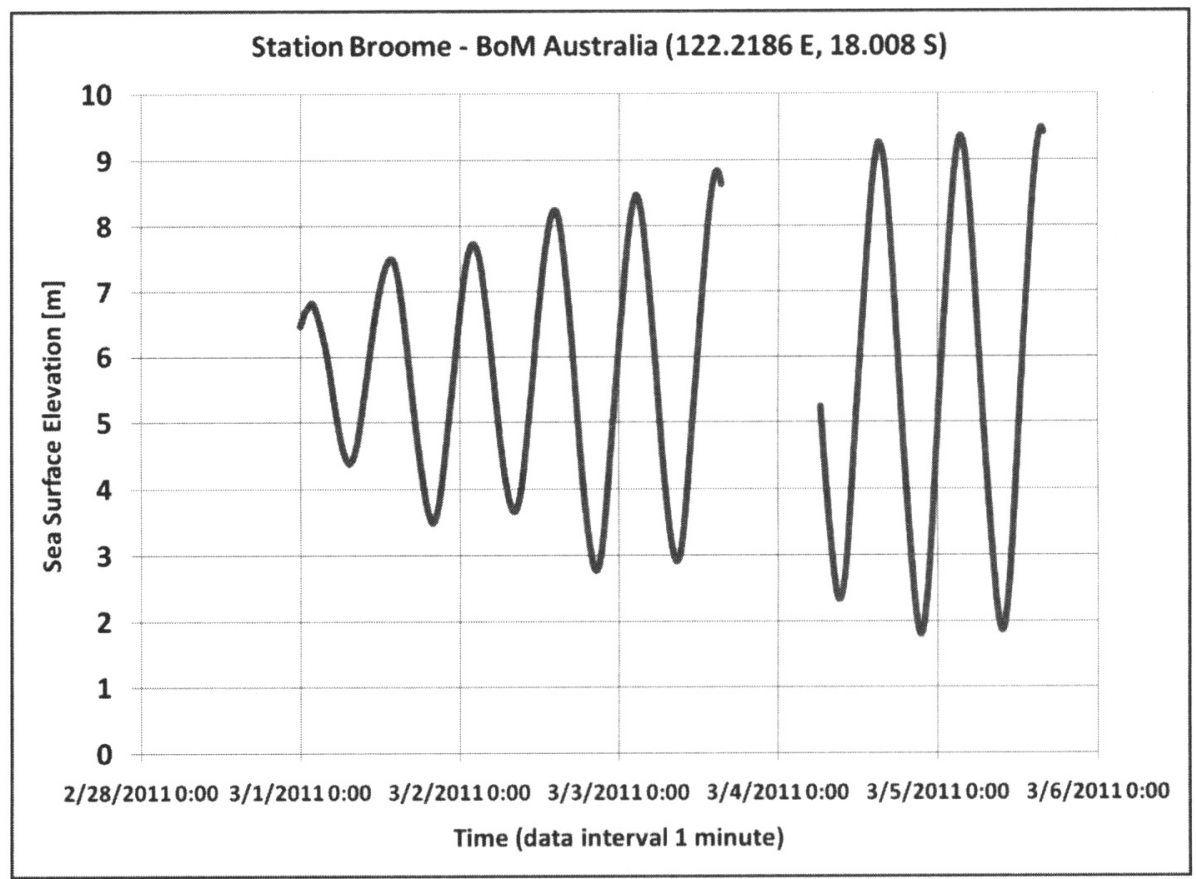

Figure 4. Example of detailed sea surface at Broome Station as observed on 1-5 March 2011. The detailed curves are part of the 30 days observation used in the estimation of tidal characteristics. 


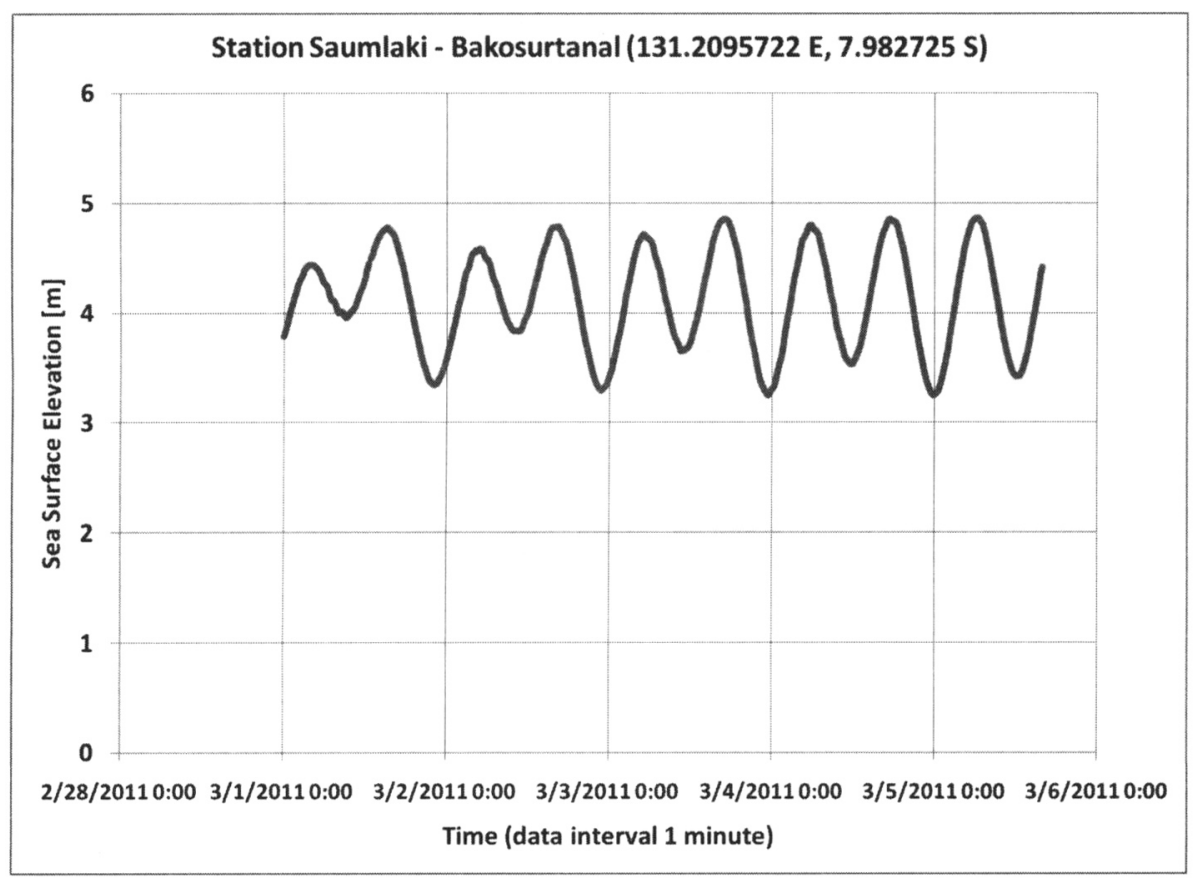

Figure 5. Example of sea surface detail at Saumlaki Station as observed during 1-5 March 2011. The detailed curves are part of the 30 days observation used in the estimation of tidal characteristics.

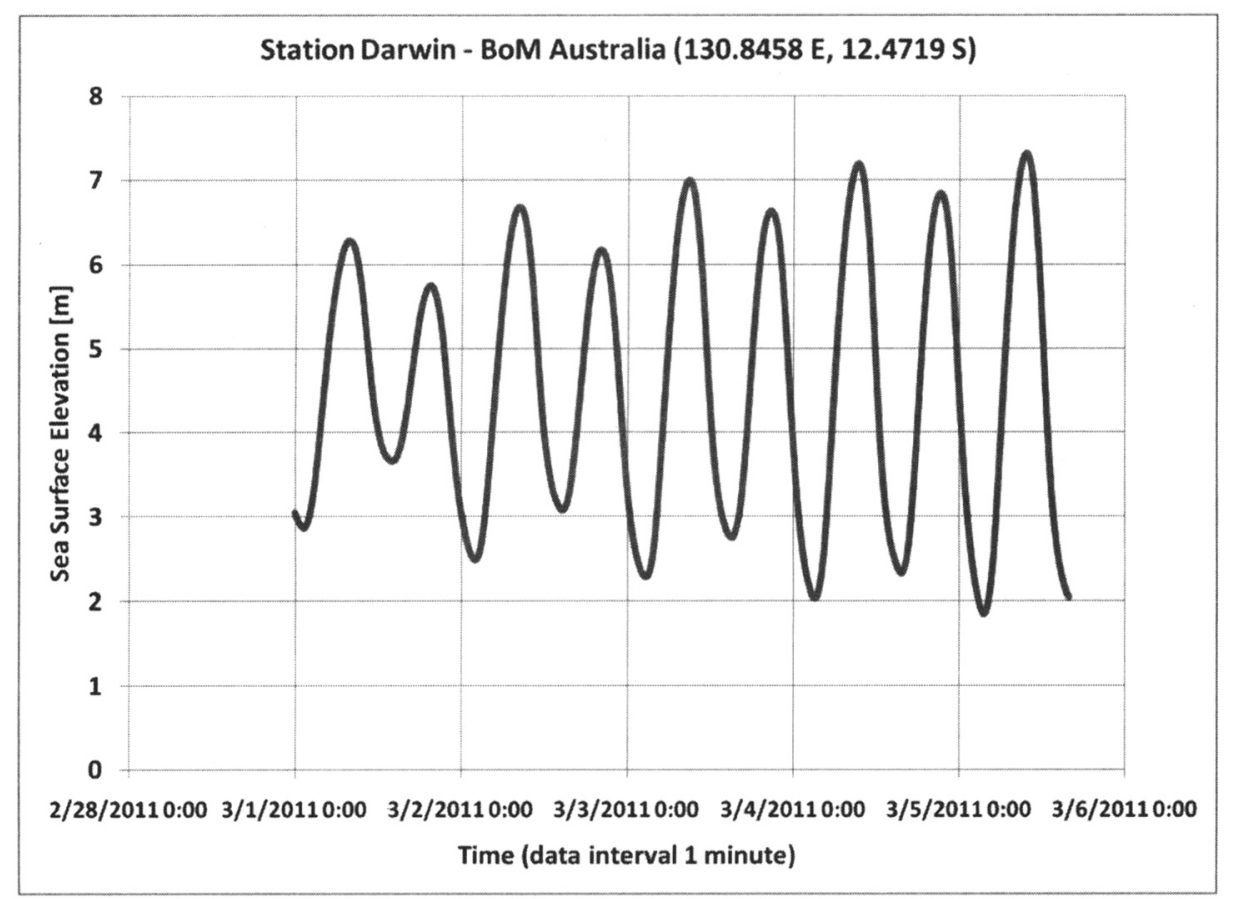

Figure 6. Example of sea surface detail at Darwin Station as observed during 1-5 March 2011. The detailed curves are part of the 30 days observation used in the estimation of tidal characteristics. 


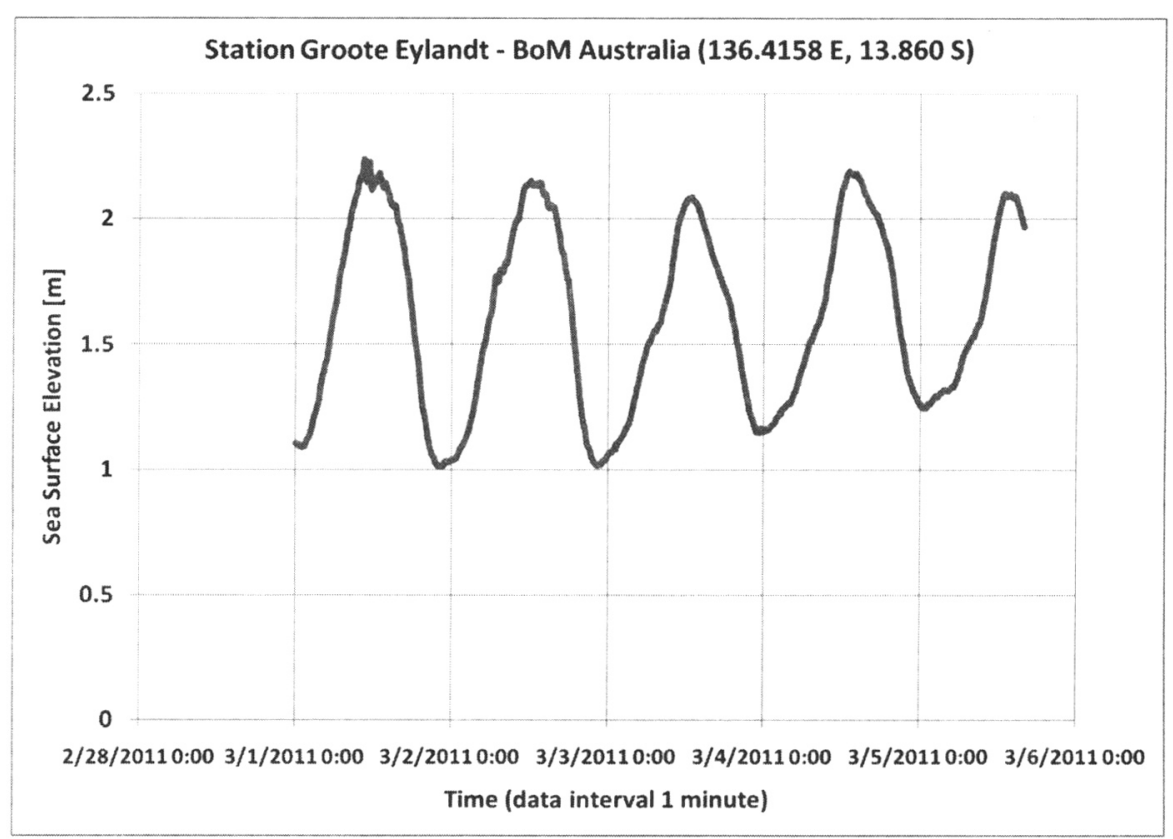

Figure 7. Example of sea surface detail at Groote Eylandt Station as observed during 1-5 March 2011. The detailed curves are part of the 30 days observation used in the estimation of tidal characteristics.

\section{RESULTS AND DISCUSSION}

\section{Tidal constituent and type}

In general, the results of this study confirm that of Wyrtki (1961), except at Karumba and Groote Eylandt (Table 1). The current study shows that there are four main constituents composing of two main tidal types, i.e. semidiurnal principal lunar (M2) and principal solar (S2); diurnal luni-solar (K1) and principal lunar (O1). Those can be dealt with together and geographically will evoluted into other types (Wyrtky, 1961). Mixed types are pronounced in the deep sea/ocean; and for instance, a fourth-diurnal of M4 is generated by $\mathrm{M} 2$ with double angular speed in the shallower waters (Pugh, 1987). The mixed type in Arafura and Timor sea most probably are caused by M2 and/or S2 propagation from Indian ocean, and K1 and/or O1 propagation from Western Pacific Ocean (Wyrtki, 1961; Robertson, 2010).

Two types of tidal are observed in the Timor Sea. The main tidal in the northern part consists of mixed prevailing semidiurnal (see Table 1 on Timor, Rote, and Darwin), but semidiurnal tidal is the main type in the southern part of Timor Sea (see Table 1 on Broome). Timor Sea which is part of the working region of the ATSEA Project includes the Ombai strait which indicates semidiurnal type of mixed tide (Table 1). Those types have been detected also by four mooring buoys in Timor Passage and another 1 in Ombai Strait of INSTANT Project (Indonesia Stratification and Transport Project) (Robertson, 2010).

In the area of Arafura Sea, which is larger than the Timor Sea, three types of tidal could be observed. Semidiurnal mixed tide is the main type found in the northern part of Arafura (see Table 1 on Tanimbar Northeast and Saumlaki), diurnal mixed tide is observed (see Table 1 on Groote Eylandt) in the southwestern part in which according to Wyrtki (1961), is semidiurnal mixed; and diurnal in the southeastern area (see Table 1 on Karumba) which is in contrast with Wyrtki's semidiurnal mixed. It is interesting to note the difference of tidal type found in this study and that of Wyrtki's. Spectral analysis shows that both stations are dominated by diurnal constituents (K1 and O1) with frequency of $\sim 0.04 \mathrm{cph}$ and periods of 23.93 hours (Figure 8 ) in support of the result of form factor. Furthermore, the difference of power spectrum between diurnal and semidiurnal at Karumba is more significant than that of Groote Eylandt. Semidiurnal (frequency $\sim 0.08 \mathrm{cph}$ ) and fourth-diurnal (freq. $\sim 0.16 \mathrm{cph}$ ) constituents at Groote Eylandt are slightly higher than that of Karumba station. 
Tabel 1. Tidal Constituents and Type in Arafura-Timor Sea Region

\begin{tabular}{|c|c|c|c|c|c|c|c|c|c|}
\hline $\begin{array}{l}\text { Station/ } \\
\text { Location }\end{array}$ & & M2 & S2 & K1 & 01 & M4 & $\begin{array}{l}\text { Form Factor } \\
\text { (FF) }\end{array}$ & $\begin{array}{l}\text { Tidal type } \\
\text { result from } \\
\text { this study }\end{array}$ & $\begin{array}{c}\text { Tydal type } \\
\text { derived from } \\
\text { Wyrtki (1961) }\end{array}$ \\
\hline \multirow{2}{*}{ Ombai } & Amplitude [m] & 0.556 & 0.252 & 0.283 & 0.177 & 0.002 & \multirow{2}{*}{0.570} & \multirow{2}{*}{$\begin{array}{l}\text { Mixed, mainly } \\
\text { Semidiurnal }\end{array}$} & \multirow{2}{*}{$\begin{array}{l}\text { Mixed, mainly } \\
\text { Semidiurnal }\end{array}$} \\
\hline & Phase [degree] & 99.780 & 142.610 & 177.350 & 165.590 & 321.140 & & & \\
\hline \multirow{2}{*}{ Timor } & Amplitude [m] & 0.641 & 0.304 & 0.313 & 0.196 & 0.008 & \multirow{2}{*}{0.539} & \multirow{2}{*}{\begin{tabular}{|l} 
Mixed, mainly \\
Semidiurnal
\end{tabular}} & \multirow{2}{*}{$\begin{array}{l}\text { Mixed, mainly } \\
\text { Semidiurnal }\end{array}$} \\
\hline & Phase [degree] & 112.450 & 157.540 & 182.560 & 171.050 & 321.740 & & & \\
\hline \multirow{2}{*}{ Rote } & Amplitude [m] & 0.759 & 0.429 & 0.270 & 0.166 & 0.006 & \multirow{2}{*}{0.367} & \multirow{2}{*}{$\begin{array}{l}\text { Mixed, mainly } \\
\text { Semidiurnal }\end{array}$} & \multirow{2}{*}{$\begin{array}{l}\text { Mixed, mainly } \\
\text { Semidiurnal }\end{array}$} \\
\hline & Phase [degree] & 69.270 & 120.610 & 173.410 & 162.870 & 282.340 & & & \\
\hline \multirow{2}{*}{$\begin{array}{l}\text { Tanimbar } \\
\text { Northeast }\end{array}$} & Amplitude [m] & 0.609 & 0.212 & 0.294 & 0.209 & 0.004 & \multirow{2}{*}{0.613} & \multirow{2}{*}{$\begin{array}{l}\text { Mixed, mainly } \\
\text { Semidiurnal }\end{array}$} & \multirow{2}{*}{\begin{tabular}{|l} 
Mixed, mainly \\
Semidiurnal
\end{tabular}} \\
\hline & Phase [degree] & 147.620 & 203.900 & 195.480 & 185.800 & 60.520 & & & \\
\hline \multirow{2}{*}{$\begin{array}{l}\text { Tanimbar } \\
\text { Saumlaki }\end{array}$} & Amplitude $[\mathrm{m}]$ & 0.612 & 0.216 & 0.297 & 0.209 & 0.003 & \multirow{2}{*}{0.611} & \multirow{2}{*}{\begin{tabular}{|l} 
Mixed, mainly \\
Semidiurnal
\end{tabular}} & \multirow{2}{*}{$\begin{array}{l}\begin{array}{l}\text { Mixed, mainly } \\
\text { Semidiurnal }\end{array} \\
\end{array}$} \\
\hline & Phase [degree] & 146.630 & 202.220 & 193.880 & 184.170 & 53.020 & & & \\
\hline \multirow{2}{*}{ Papua-1 } & Amplitude [m] & 0.517 & 0.164 & 1.162 & 0.882 & 0.005 & \multirow{2}{*}{3.001} & \multirow{2}{*}{$\begin{array}{l}\text { Mixed, mainly } \\
\text { Diurnal }\end{array}$} & \multirow{2}{*}{$\begin{array}{l}\text { Mixed, mainly } \\
\text { Diurnal }\end{array}$} \\
\hline & Phase [degree] & 13.180 & 72.780 & 286.580 & 251.900 & 69.900 & & & \\
\hline \multirow{2}{*}{ Papua-2 } & Amplitude [m] & 0.212 & 0.072 & 0.829 & 0.665 & 0.004 & \multirow{2}{*}{5.264} & \multirow{2}{*}{ Diurnal } & \multirow{2}{*}{ Diurnal } \\
\hline & Phase [degree] & 154.490 & 219.810 & 274.610 & 243.750 & 239.440 & & & \\
\hline \multirow{2}{*}{ Darwin } & Amplitude [m] & 1.699 & 0.957 & 0.583 & 0.303 & 0.048 & \multirow{2}{*}{0.334} & \multirow{2}{*}{$\begin{array}{l}\text { Mixed, mainly } \\
\text { Semidiurnal }\end{array}$} & \multirow{2}{*}{$\begin{array}{l}\text { Mixed, mainly } \\
\text { Semidiurnal }\end{array}$} \\
\hline & \begin{tabular}{|l} 
Phase [degree] \\
\end{tabular} & 268.570 & 317.560 & 208.660 & 196.260 & 99.590 & & & \\
\hline \multirow{2}{*}{ Karumba } & Amplitude [m] & 0.057 & 0.027 & 0.793 & 0.586 & 0.000 & & Diurnal & Mixed, mainly \\
\hline & Phase [degree] & 271.570 & 65.670 & 177.080 & 114.330 & 350.000 & & & Semidiurnal \\
\hline Groote & Amplitude [m] & 0.150 & 0.050 & 0.254 & 0.209 & 0.004 & & Mixed, mainly & Mixed, mainly \\
\hline Eylandt & \begin{tabular}{|l|} 
Phase [degree] \\
\end{tabular} & 52.400 & 136.690 & 235.180 & 166.970 & 26.990 & 2.310 & & Semidiurnal \\
\hline & Amplitude [m] & 2.324 & 1.488 & 0.262 & 0.157 & 0.072 & & & Semidiurnal \\
\hline & Phase [degree] & 60.080 & 126.420 & 172.230 & 161.750 & 59.100 & & & \\
\hline
\end{tabular}
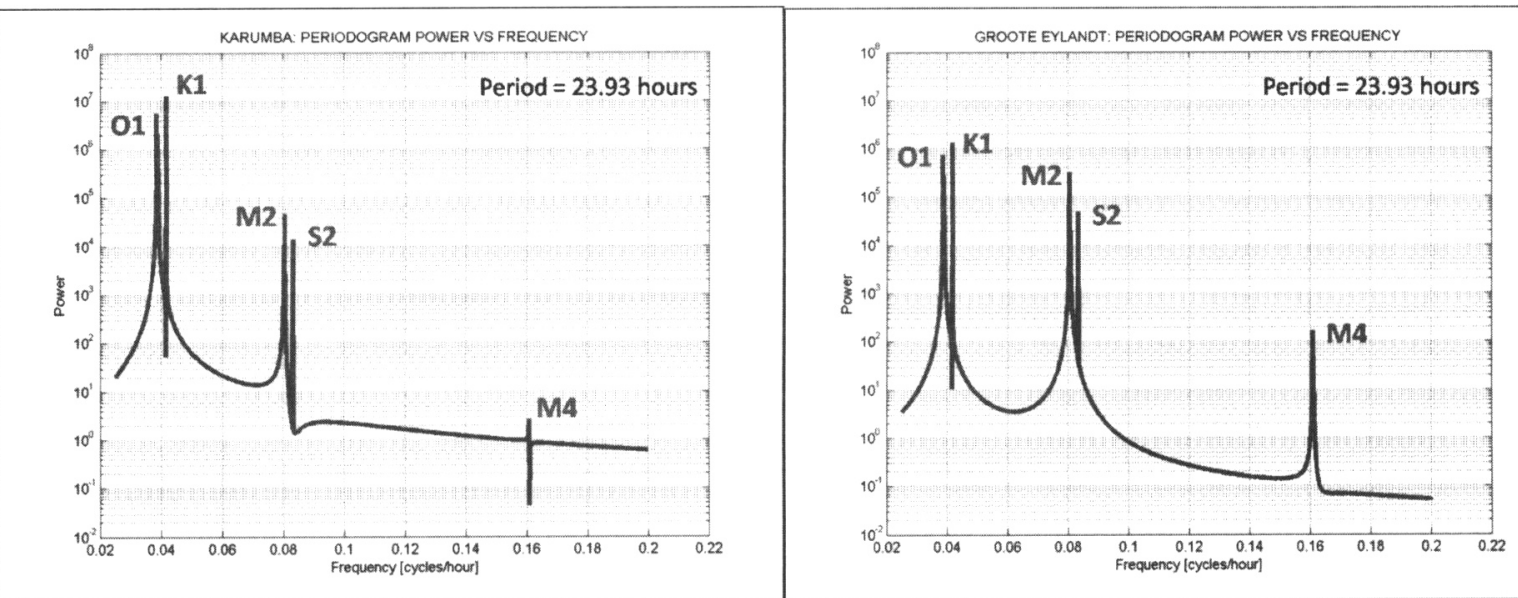

Figure 8. Power spectrum of Karumba (a) and Groote Eylandt (b) that shows similarities in tidal pattern. Diurnal tidal constituent ( 1 1 \& O1) is more dominant than the semidiurnal (M2 \& S2) and fourth-diurnal (M4). Both stations tend to have similar diurnal period of 23.93 hours.

\section{Tidal range, current, and transport}

The hydrodynamics of Arafura and Timor Sea, in general, are generated by tidal forcing in addition to wind forcing (Hantoro, 1994) and stratified water masses (Tubalawony, 2004). The surface tidal current is more dominant in the coastal area or shallow waters than in deep waters. Over very complex bathymetry, an internal wave may be triggered by tidal current (Herman, 2005). Speed direction pattern changes dinamically following the periodic amplitude gradients (Pranowo et al., 2004).

The tidal range of Timor region is in between maximum of 5.3782 meters as estimated at Darwin and minimum of 2.3174 meters as indicated at Ombai. The tidal in Arafura Sea ranges from maximum of 2.9696 meters at Karumba and minimum of 2.3973 meters at Tanimbar (Table 2). 
Therefore, the maximum gradient of elevation at Darwin triggers a very maximum east velocity component of $50.559 \mathrm{~cm} / \mathrm{s}$ with north component of $19.4289 \mathrm{~cm} / \mathrm{s}$. Multiplication of the velocity with total depth (Egbert and Erofeeva, 2002) at the stations reveals the maximum of tidal transport about $884.2056 \mathrm{~m}^{2} / \mathrm{s}$ for east component, and
$503.7316 \mathrm{~m}^{2} / \mathrm{s}$ for north component at Ombai (Table 3).

The second maximum of tidal transport after Ombai is Timor with station depth of 1032.04 meters. The two stations are located along the Indonesian Through flow pathways (Pranowo et al., 2006; Gordon et al., 2010).

Table 2. Tidal Elevation (Z) Estimated for Year 2010 with 1 Minute Data Interval

\begin{tabular}{|l|c|c|c|}
\hline \multirow{2}{*}{ Station } & \multicolumn{3}{|c|}{ Z [m] } \\
\cline { 2 - 4 } & $\mathbf{Z ~ m a x}$ & $\mathbf{Z ~ m i n}$ & Z range \\
\hline Ombai & 1.1034 & -1.214 & 2.3174 \\
\hline Timor & 1.2624 & -1.3992 & 2.6616 \\
\hline Darwin & 2.48450 & -2.89370 & 5.3782 \\
\hline Tanimbar & 1.10700 & -1.29030 & 2.3973 \\
\hline Papua-1 & 1.8828 & -2.8094 & 4.6922 \\
\hline Papua-2 & 1.8461 & -1.4495 & 3.2956 \\
\hline Karumba & 1.52690 & -1.44270 & 2.9696 \\
\hline
\end{tabular}

Table 3. Estimated Tidal Current for Year 2010 with 1 Minute Data Interval

\begin{tabular}{|c|c|c|c|c|c|c|}
\hline \multirow{2}{*}{ Station } & \multicolumn{3}{|c|}{$\mathrm{U}[\mathrm{cm} / \mathrm{s}]$} & \multicolumn{3}{|c|}{$\mathrm{V}[\mathrm{cm} / \mathrm{s}]$} \\
\hline & $\mathrm{U} \max$ & $\mathrm{U} \min$ & $\mathrm{U}$ average & $V \max$ & $V \min$ & $\mathrm{V}$ average \\
\hline Ombai & 46.1915 & -48.1397 & 0.000715 & 26.3153 & -27.553 & 0.000204 \\
\hline Timor & 12.4824 & -12.338 & -0.00046 & 4.9367 & -4.8418 & -0.00011 \\
\hline Darwin & 50.559 & -47.1227 & -0.00748 & 19.4289 & -22.6334 & 0.001820 \\
\hline Papua-1 & 41.3209 & -43.8577 & -0.00943 & 39.8652 & -33.6591 & 0.009153 \\
\hline Papua-2 & 65.8719 & -70.8679 & -0.01730 & 29.5069 & -27.3447 & 0.007087 \\
\hline Tanimbar & 2.7443 & -3.489 & -0.00082 & 1.4495 & -1.0477 & -0.00018 \\
\hline Karumba & 6.8081 & -6.0766 & 0.001687 & 6.86 & -7.1471 & -0.00164 \\
\hline
\end{tabular}

Table 4. Tidal Transport (Depth Average) Estimated for Year 2010 with 1 Minute Data Interval

\begin{tabular}{|l|c|c|c|c|c|c|c|}
\hline \multirow{2}{*}{ Station } & Station Depth & \multicolumn{3}{|c|}{$\mathbf{U}[\mathrm{m} 2 / \mathrm{s}]$} & \multicolumn{3}{c|}{ V [m2/s] } \\
\cline { 3 - 8 } & {$[\mathrm{m}]$} & $\mathbf{U}$ max & $\mathbf{U}$ min & U average & V max & V min & V average \\
\hline Ombai & 1914.22 & 884.2056 & -921.499 & 0.013679 & 503.7316 & -527.424 & 0.003899 \\
\hline Timor & 1032.04 & 128.8226 & -127.333 & -0.00477 & 50.9486 & -49.9687 & -0.00118 \\
\hline Darwin & 27.61 & 13.9573 & -13.0087 & -0.00206 & 5.3635 & -6.2482 & 0.000502 \\
\hline Tanimbar & 744.7 & 20.4367 & -25.9828 & -0.00612 & 10.7946 & -7.8022 & -0.00133 \\
\hline Papua-1 & 30.6 & 12.4218 & -13.1844 & -0.00283 & 11.9842 & -10.1185 & 0.002752 \\
\hline Papua-2 & 42.56 & 28.0374 & -30.1638 & -0.00737 & 12.5592 & -11.6389 & 0.003016 \\
\hline Karumba & 13.61 & 0.9265 & -0.8269 & 0.00023 & 50.4107 & -52.5202 & -0.01205 \\
\hline
\end{tabular}

\section{SUMMARY AND CONCLUSION}

Two types of tidal are observed in the Timor sea, i.e. mixed prevailing semidiurnal in the northern part, and semidiurnal tidal in the southern part. Semidiurnal mixed type is observed in the area of Arafura sea (northern part), including the mixed diurnal (southwestern part) and the diurnal itself (southeastern part). This study shows that tidal range in the Arafura-Timor Seas is between 2.3 $\mathrm{m}$ and $5.4 \mathrm{~m}$. Tidal range maximum of $5.3 \mathrm{~m}$ is observed in Darwin. In the Arafura Sea, the highest tidal range is estimated at $4.69 \mathrm{~m}$ in the southwest of Papua. 


\section{REFERENCES}

ATSEA. 2010. ATSEA Cruise Report. Jakarta: ATSEA Program, $214 \mathrm{p}$.

Charlier, R.H. 2003. "A "sleeper" Awakes: Tidal Current Power: Renewable and Sustainable Energy Reviews". 7(2003):515-529.Doi:10.1016/ S1364-0321(03)00079-0.

Egbert, G.D. and S.Y. Erofeeva, 2002. Efficient Inverse Modeling of Barotropic Ocean Tides. Am. Met. Soc., (19): 183-204.

Emery, W.J. and R.E. Thomson. 2004. Data Analysis Methods in Physical Oceanography. $2^{\text {nd }}$ and Revised Eds., Elsevier, 404-554.

GEBCO, 2008. General Bathymetric Chart of the Oceans. http://www.gebco. net/

Gordon, A.L., J. Sprintall, H.M. Van Aken, R.D. Susanto, S. Wijffels, R. Molcard, A. Ffield, W. Pranowo, and S. Wirasantosa. 2010. The Indonesian Throughflow during 2004-2006 as observed by the INSTANT program. Dyn. Atmosph. Ocean., 50 (2): 115-128, doi:10.1016/j. dynatmoce.2009.12.002.

Hantoro, W.S., 1994. Geologi dan Sumber Daya Air Wilayah Pesisir Utara Lintasan Liquica-Los Palos, Provinsi Timor Timur. Prosiding Hasilhasil Penelitian Puslitbang Geoteknologi LIPI, 464-488.

Herman, R. 2005. Harmonic analysisis and the prediction of tide. Mathematic and Statistics. UNCW. $60 \mathrm{pp}$.

IHO Map Sheet 3. International Hydrographic Organization.
Pranowo, W.S., A.R. Tisiana D. Kuswardhani, T.L. Kepel, U.R. Kadarwati, S. Makarim, and S. Husrin. 2006. Ekspedisi INSTANT 2003-3005: Menguak Arus Lintas Indonesia. In Supangat, A., I.S. Brodjonegoro, A.G. Ilahude, I. Jaya, T.R. Adi., Pusat Riset Wilayah Laut dan Sumberdaya Non-hayati, Badan Riset Kelautan dan Perikanan, Departemen Kelautan dan Perikanan, Cetakan pertama Januari 2006.

Pranowo, W.S., Y. Herdiani, and I.M. Radjawane, 2004. Barotropical Tidal \& Wind-Driven Larval Transport on Saleh Bay, Sumbawa, Indonesia. Proceedings The Twelfth OMISAR Workshop on Ocean Models, 7-10 September 2004, Dalian, P.R. China.ITF

Pugh, D.T. 1987. Tides, Surges and Mean Sea-Level. John Wiley \& Sons.

Robertson, R. 2010. Tidal Currents and Mixing at the ISTANT Mooring Locations. Dyn. Atmosph. Ocean. 50 (2): 331-373, doi:101.106/j. dynatmoce.2010.02.004.

Setiawan, A. 2007. Modelling Over and Compound tides of the Irish and Celtic Seas Using Variational Data Assimilation Methods. Ph.D. thesis, University of Hamburg.

Sihotang, J. 2010. Masalah Perbatasan Wilayah Laut Indonesia di Laut Arafura dan Laut Timor. Jurnal Penelitian Politik, 7 (1), 119-132.

Tubalawony, S. 2004. Karakteristik Fisik Massa Air Laut Timor pada Musim Timur. Ichthyos, 3 (2), Januari 2004: 51-54.

Walter, R.A. and C. Heston. 1982. Removing TidalPeriod Variations from Time-Series Data Using Low-Pass Digital Filters. J. Phys. Ocean. (12): $112-115$.

Wyrtki, K. 1961. Physical Oceanography of the Southeast Asian Waters. NAGA REPORT Vol. 2, $225 \mathrm{pp}$. 